DOI https://doi.org/10.18551/rjoas.2020-12.19

\title{
THE EVALUATION ON RECOVERY PHASE OF POST-SUBMERGED RICE
}

\author{
Irmawati ${ }^{*}$, Syawal Yernelis, Sulistyaningsih Lidwina N., Susilawati, Yakup, Ronaldo Edo \\ Department of Agronomy, Faculty of Agriculture, University of Sriwijaya, Indonesia \\ *E-mail: irmawati@fp.unsri.ac.id
}

\begin{abstract}
Rice plants may experience submergence stress in various phases of plant development due to the unpredictable flash flooding occurred during planting season. Plants' recovery phase after submergence is an important phase that determines plant survival. The character of plant growth and development during this recovery phase can be important information in determining the tolerance of plants to submerged stress. Therefore, this study was conducted to evaluate the recovery phase of post-submerged rice plants indicated by the character of plant growth and development. Split plot design was utilized with rice cultivars as the main plot and submergence time subplot. Two cultivars used were IR 42 (non-tolerant cultivar) and Inpari 30 (tolerant cultivar), while submergence time consisted of three phases, namely: 1) generative initial phase = 42 days after transplanting (DAT); 2) active tillering phase $=28$ DAT, and 3) early vegetative phase $=7$ DAT. Plant samplings were conducted for six times: right before submergence (t0), right after submergence (t1), 4 days after submergence (t2), 7 days after submergence (t3), 10 days after submergence (t4) and 14 days after submergence (t5). Results showed that both cultivar and submergence time showed a non-significant effect on plant growth during recovery phase, except for leaf greenness parameter. The recovery pattern of rice plants after experiencing submergence stress was generally not influenced by the age of the plants during stress. In addition, improvements in plant growth characters began to appear after 10 days of recovery.
\end{abstract}

\section{KEY WORDS}

Recovery phase, rice growth, submergence.

Flooding has been a major issue for rice cultivation in lowland area, including swampland in South Sumatra. Flash flooding frequently occurs in South Sumatra swamp area mostly will lead rice plants to submergence condition for several days. Manzanilla et al. (2011) reported that the effect on rice growth depended on duration and depth of flash floods where it could reach $77 \%$ of damage if lasted for two weeks and more than $100 \mathrm{~cm}$ of water depth. One of plant strategies to escape from submergence is by elongating the stem to reach oxygen above water surface (Anandan et al., 2012; Gautam et al., 2014; Oladosu et al., 2020). However, this will exhaust carbohydrate reserves that later will be beneficial for plant growth recovery after desubmergence (Panda \& Sarkar, 2014). While plant mechanism during submergence is an essential factor, the recovery phase after submergence is also critical for plant survival (Buraschi et al., 2020; Luo et al., 2011; Ye et al., 2016). Whether it can survive only for several days after submergence or it can continue its growth until producing yield. Thus, this research was conducted to evaluate the recovery phase of rice plants after being submerged on three different ages. The character of plant growth and development during this recovery phase can be important information in determining the tolerance of plants to submerged stress.

\section{METHODS OF RESEARCH}

Split plot design was used with three replicates, where rice cultivars served as the main plot and submergence time as subplot. The cultivars used were IR 42 (non-tolerant cultivar) and 
Inpari 30 (Ciherang sub-1, a tolerant cultivar). The subplot consisted of three submergence phases, namely: 1 ) generative initial phase $=42$ days after transplanting (DAT); 2) active tillering phase = 28 DAT; and 3) early vegetative phase = 7 DAT. Rice seeds were first sown in a nursery tray and kept for 21 days in the nursery before transplanted into a single pot. Since plant age was different for each treatment, plant sowing was carried out in three different times following the treatments so that all plants could later be submerged at the same time. Submergence condition was given to the plants by placing the pots in a concrete tank with the size of approximately $4 \mathrm{~m} \times 3 \mathrm{~m} \times 2 \mathrm{~m}$. Water depths was first set for about $75 \mathrm{~cm}$ from base of the plants and then monitored daily to keep the submergence stress condition for 10 days.

Plant samplings were carried out for six times: $\mathrm{t} 0$ = right before submergence started; $\mathrm{t} 1=$ right after submergence ended; $\mathrm{t} 2=4$ days after submergence ended; $\mathrm{t} 3=7$ days after submergence; $\mathrm{t} 4=10$ days afters submergence; $\mathrm{t} 5=14$ days after submergence. Destructive sampling was carried out by uprooting 2 plants in each research unit to obtain data on variables of plant length, leaf area, leaf greenness level, tiller number, root dry weight, stem dry weight, leaf dry weight and total plant dry weight. Leaf greenness level was measured using SPAD tool indicating leaf chlorophyll content. Analysis of variance then was used to analyse the effect of treatments on observed parameters, while the difference among treatments was analysed using least significant difference (LSD) test.

\section{RESULTS AND DISCUSSION}

Data analysis was performed separately between during submergence condition and during recovery period.

Table 1 - Analysis of variance on growth parameters during 10 days submergence

\begin{tabular}{|c|c|c|c|c|}
\hline \multirow{2}{*}{ No } & \multirow{2}{*}{ Parameter } & \multicolumn{3}{|l|}{ F Value } \\
\hline & & $\mathrm{R}$ & $\mathrm{C}$ & $\mathrm{C} \times \mathrm{R}$ \\
\hline 1. & Plant length increment $(\mathrm{cm})$ & $0.68^{\mathrm{ns}}$ & $0.02^{\text {ns }}$ & $0.32^{\text {ns }}$ \\
\hline 2. & Tiller increment & $0.36^{\text {ns }}$ & $0.08^{\mathrm{ns}}$ & $1.44^{\mathrm{ns}}$ \\
\hline 3. & Leaf greenness & $48.66^{\star *}$ & $0.01^{\mathrm{ns}}$ & $0.49^{\text {ns }}$ \\
\hline 4. & Leaf area increment $\left(\mathrm{cm}^{2}\right)$ & $1.78^{\mathrm{ns}}$ & $0.89^{\text {ns }}$ & $0.92^{\text {ns }}$ \\
\hline 5. & Root length increment (cm) & $2.56^{\text {ns }}$ & $2.32^{\text {ns }}$ & $3.26^{\text {ns }}$ \\
\hline 6. & Root dry weight increment (g) & $2.30^{\mathrm{ns}}$ & $1.48^{\mathrm{ns}}$ & $1.01^{\mathrm{ns}}$ \\
\hline 7. & Stem dry weight increment $(\mathrm{g})$ & $3.31^{\mathrm{ns}}$ & $1.01^{\mathrm{ns}}$ & $2.26^{\mathrm{ns}}$ \\
\hline 8. & Leaf dry weight increment (g) & $7.23^{*}$ & $6.48^{\text {ns }}$ & $1.46^{\mathrm{ns}}$ \\
\hline \multirow[t]{3}{*}{9.} & Total dry weight increment $(\mathrm{g})$ & $3.12^{\mathrm{ns}}$ & $0.31^{\mathrm{ns}}$ & $1.16^{\text {ns }}$ \\
\hline & $\mathrm{F} 0.05$ & 4.46 & 18.51 & 4.46 \\
\hline & F 0.01 & 8.65 & 98.50 & 8.65 \\
\hline
\end{tabular}

$R=$ plant age during submergence; $C=$ cultivar; ${ }^{* *}=$ highly significant; ${ }^{*}=$ significant; ns = non-significant .

Table 1 shows analysis of variance of growth parameters during submergence condition. Based on the results, it was found that both cultivar $(C)$ and the interaction between cultivar and plant age during submergence $(R)$ showed no significant differences in all observed parameters. Meanwhile, the difference in plant age gave a very significant effect on the variable of leaf greenness and significantly affected leaf dry weight increment.

The least significant difference test (LSD) was then carried out to see the differences among three subplot treatments (Table 2). Results showed that R3 plants or plants that were submerged at the age of 7 DAT experienced the most severe impact due to the submerged conditions based on the variables of leaf greenness. Meanwhile, based on the variable of leaf dry weight increment, R2 was the treatment with the greatest negative effect compared to other treatments. R3 plants had the lowest average leaf greenness value, with 17.55 or twice less than the R1 and R2 treatments with values of 38.81 and 38.21 , respectively. This may be due to 
the difference in age between the three treatments where R3 plants were the plants with the youngest age so they had less leaf chlorophyll content. Measurements of leaf greenness were carried out on leaves with the same position, a fully developed leaf in the uppermost position. Plants with more mature age generally will have more leaves, so when stress occurs, translocation of nutrients (especially nitrogen) from old leaves in the lower position to leaves in the upper position will occur more intensively than in younger plants which ultimately led to a significant difference in the chlorophyll levels identified by the greenness of the leaves. Revatipadale et al. (2019) also reported that higher chlorophyll content was found in older plants.

Table 2 - LSD test of plant age during submergence treatment $(R)$ on leaf greenness and leaf dry weight increment during 10 days submergence

\begin{tabular}{lll}
\hline Treatments & Parameter & \\
\hline & Leaf greenness & \\
R1 & 38.81 & $\mathrm{~b}$ \\
R2 & 38.21 & $\mathrm{~b}$ \\
R3 & 17.55 & $\mathrm{a}$ \\
\hline LSD 0.01 & 8.24 & \\
\hline & Leaf dry weight increment $(g)$ & $\mathrm{b}$ \\
R1 & $(0.02)$ & $\mathrm{a}$ \\
R2 & $(0.89)$ & $\mathrm{b}$ \\
R3 & $(0.07)$ & \\
\hline LSD 0.05 & 0.59 & \\
\hline
\end{tabular}

The numbers followed by the same letter in the same column indicates non-significant difference on LSD 0.01 and 0.05 . Numbers in the brackets indicate negative values.

Since there was a large gap between three treatments due to the difference on plant age, the absolute mean value could not be used to compare the effect of treatments. Therefore, the increment value then was considered more accurate to evaluate the effect of submergence stress on plant growth with different ages. In leaf dry weight increment parameter, a negative value was obtained which indicated a decrease in dry weight accumulation on leaves during submergence stress. R2 plants had the largest decrease in leaf dry weight compared to other treatments with $0.89 \mathrm{~g}$, while R1 plants had the lowest decrease with only $0.02 \mathrm{~g}$. The decrease in leaf dry weight was probably caused by higher rate of leaves senescence due to submergences.

During 10 days of submergence, rice plants in all treatments experienced a very drastic increase in plant height as seen in Fig 1. This was due to stem elongation as plant escape strategy to get out of water surface to obtain oxygen. This escape mechanism has been reported by many research results (Bailey-Serres et al., 2010; Elanchezhian et al., 2013; Irmawati et al., 2016; Nishiuchi et al., 2012; Singh et al., 2014). After submergence was ended, plant length drastically decreased due to a high rate of leaf senescence which occurred in all treatments. The decreasing trend generally continued until 7 days after submergence though the decrease was not so apparent. Plant length increase started when the plants had been through 10 days of recovery phase although the response of each treatment was still varied. This indicated that after 10 days of recovery, plant growth as shown in plant length was started to improve and stable.

During recovery phase, 4 sampling activities were conducted to evaluate recovery of rice growth after experiencing submergence stress. Plants were given a total of 14 days of recovery period, where the observation was carried out in stages divided into 4 periods: 4 days, 7 days, 10 days and 14 days of recovery. Data analysis was also carried out separately for each observation period. 


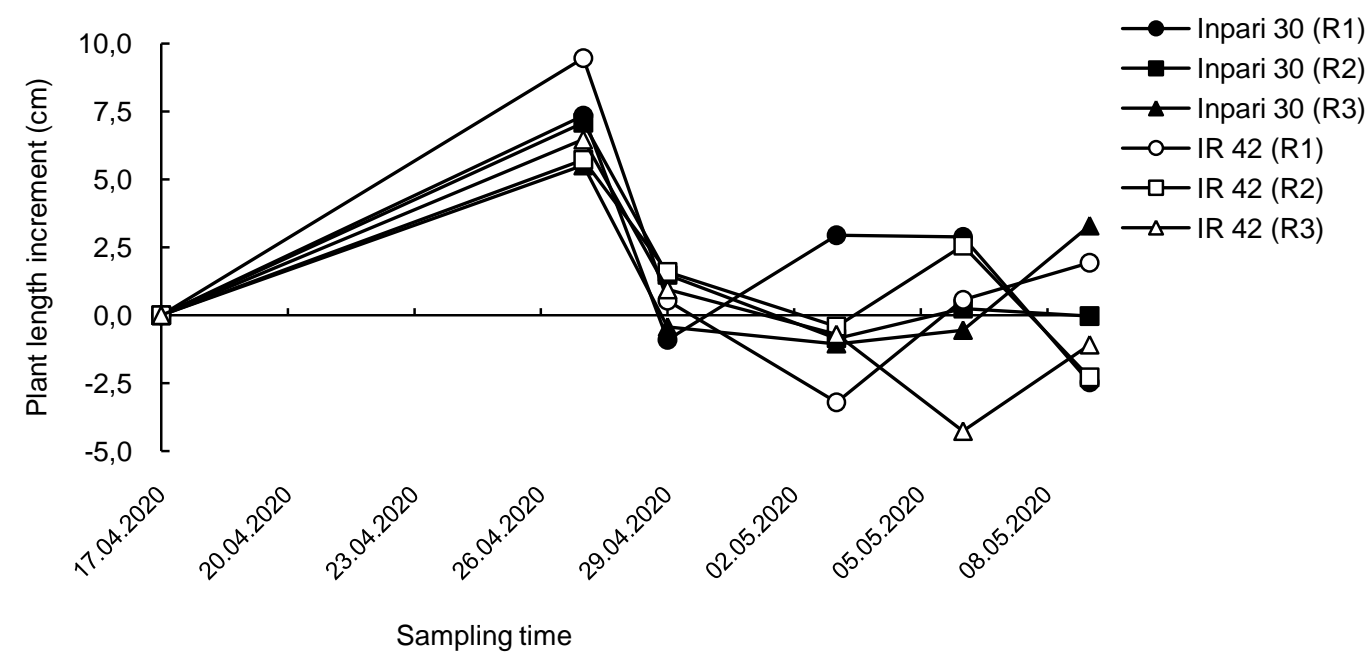

Figure 1 - Plant length increment of two rice cultivars during 10 days submergence and 14 days recovery phase

Table 3 shows analysis of variance on growth parameter of rice plants during recovery phase. Based on the results, it was clear that no significant effect of cultivar difference on all growth parameters. Meanwhile, only leaf greenness level showed significant effect in all stages of recovery period. Stem dry weight increment was significantly affected by the differences of plant age at 10 days recovery. The interaction of cultivar and plant age only affected plant growth significantly at 4 days recovery, especially in growth parameter of leaf area increment, stem dry weight increment, leaf dry weight increment and total dry weight increment.

Based on LSD results in Table 4, it was found that in the parameter of leaf area increment, IR 42 had a significant increase in leaf area compared to Inpari 30 in R1 treatment. This did not occur in other treatments with younger plant ages. Meanwhile, among Inpari 30 cultivar, R2 plant had the highest leaf area increase with $62 \mathrm{~cm}^{2}$, but this increase was not significantly different when compared to the IR 42 cultivar. R1 plants still had a decrease in leaf area with $11.3 \mathrm{~cm}^{2}$. While for stem dry weight and leaf dry weight increment, significant differences were only seen in the same cultivars. R1 plants on IR 42 variety had the highest increase in stem and leaf dry weight compared to other treatments, with $1.22 \mathrm{~g}$ and $0.76 \mathrm{~g}$, respectively. Inpari 42 also had a total plant dry weight increment which was significantly higher than Inpari 30 in treatment R1, which was $3.83 \mathrm{~g}$, but this did not occur in the treatment with younger plants where there was no difference between treatments.

Table 3 - Analysis of variance on growth parameters during 14 days recovery phase

\begin{tabular}{|c|c|c|c|c|c|c|c|c|c|c|c|c|c|}
\hline \multirow{2}{*}{ No } & \multirow{2}{*}{ Peubah yang diamati } & \multicolumn{3}{|c|}{ F value on 4 days recovery } & \multicolumn{3}{|c|}{$\mathrm{F}$ value on 7 days recovery } & \multicolumn{3}{|c|}{ F value on 10 days recovery } & \multicolumn{3}{|c|}{$\mathrm{F}$ value on 14 days recovery } \\
\hline & & $\mathrm{R}$ & $\mathrm{C}$ & $\mathrm{C} \times \mathrm{R}$ & $\mathrm{R}$ & $\mathrm{C}$ & $\mathrm{C} \times \mathrm{R}$ & $\mathrm{R}$ & $\mathrm{C}$ & $\mathrm{C} \times \mathrm{R}$ & $\mathrm{R}$ & $\mathrm{C}$ & $\mathrm{C} \times \mathrm{R}$ \\
\hline 1. & Plant length increment $(\mathrm{cm})$ & $0.24^{\mathrm{nS}}$ & $0.05^{\text {ns }}$ & $0.04^{\text {ns }}$ & $0.03^{\text {ns }}$ & $3.05^{\mathrm{ns}}$ & $0.67^{\text {ns }}$ & $1.40^{\text {ns }}$ & $2.81^{\text {ns }}$ & $0.66^{\text {ns }}$ & $0.46^{\text {ns }}$ & $0.40^{\text {ns }}$ & $1.84^{\mathrm{ns}}$ \\
\hline 2. & Tiller increment & $2.12^{\text {ns }}$ & $0.44^{\mathrm{ns}}$ & $0.99^{\text {ns }}$ & $1.02^{\mathrm{ns}}$ & $1.18^{\mathrm{ns}}$ & $1.06^{\text {ns }}$ & $1.46^{\text {ns }}$ & $0.02^{\text {ns }}$ & $0.49^{\text {ns }}$ & $0.25^{\mathrm{ns}}$ & $1.86^{\mathrm{ns}}$ & $0.91^{\text {ns }}$ \\
\hline 3. & Leaf greenness & $43.41^{* *}$ & $0.85^{\mathrm{ns}}$ & $0.99^{\text {ns }}$ & $29.05^{\star *}$ & $5.08^{\text {ns }}$ & $1.51^{\text {ns }}$ & $7.80^{*}$ & $1.95^{\text {ns }}$ & $3.53^{\text {ns }}$ & $5.33^{*}$ & $0.37^{\text {ns }}$ & $0.01^{\text {ns }}$ \\
\hline 4. & Leaf area increment $\left(\mathrm{cm}^{2}\right)$ & $1.53^{\text {ns }}$ & $1.37^{\text {ns }}$ & $5.02^{\star}$ & $2.07^{\mathrm{ns}}$ & $1.73^{\text {ns }}$ & $1.22^{\text {ns }}$ & $0.57^{\mathrm{ns}}$ & $0.01^{\text {ns }}$ & $0.43^{\text {ns }}$ & $0.06^{\text {ns }}$ & $0.02^{\mathrm{ns}}$ & $0.50^{\text {ns }}$ \\
\hline 5. & Root length increment $(\mathrm{cm})$ & $2.43^{\text {ns }}$ & $2.57^{\text {ns }}$ & $0.51^{\text {ns }}$ & $2.68^{\text {ns }}$ & $2.08^{\text {ns }}$ & $0.50^{\text {ns }}$ & $0.37^{\text {ns }}$ & $0.07^{\text {ns }}$ & $0.73^{\text {ns }}$ & $0.95^{\mathrm{ns}}$ & $1.97^{\text {ns }}$ & $1.22^{\text {ns }}$ \\
\hline 6. & Root dry weight increment (g) & $0.87^{\text {ns }}$ & $6.66^{\text {ns }}$ & $3.72^{\text {ns }}$ & $0.21^{\text {ns }}$ & $0.23^{\text {ns }}$ & $0.51^{\text {ns }}$ & $1.30^{\mathrm{ns}}$ & $0.16^{\text {ns }}$ & $0.45^{\mathrm{ns}}$ & $0.70^{\text {ns }}$ & $0.43^{\text {ns }}$ & $0.34^{\text {ns }}$ \\
\hline 7. & Stem dry weight increment (g) & $1.74^{\mathrm{ns}}$ & $0.01^{\text {ns }}$ & $5.03^{\star}$ & $0.84^{\text {ns }}$ & $0.06^{\mathrm{ns}}$ & $1.72^{\text {ns }}$ & $4.65^{*}$ & $0.00^{\text {ns }}$ & $0.14^{\mathrm{ns}}$ & $1.63^{\text {ns }}$ & $1.47^{\mathrm{ns}}$ & $0.90^{\text {ns }}$ \\
\hline 8. & Leaf dry weight increment (g) & $3.47^{\text {ns }}$ & $0.33^{\text {ns }}$ & $6.29^{\star}$ & $1.80^{\text {ns }}$ & $0.05^{\mathrm{ns}}$ & $0.56^{\text {ns }}$ & $0.75^{\mathrm{ns}}$ & $0.04^{\mathrm{ns}}$ & $1.25^{\mathrm{ns}}$ & $2.01^{\text {ns }}$ & $1.17^{\mathrm{ns}}$ & $0.67^{\text {ns }}$ \\
\hline \multirow[t]{2}{*}{9.} & Total dry weight increment (g) & $1.39^{\text {ns }}$ & $0.58^{\text {ns }}$ & $4.99^{\star}$ & $0.65^{\text {ns }}$ & $3.85^{\mathrm{ns}}$ & $1.70^{\text {ns }}$ & $3.13^{\text {ns }}$ & $0.02^{\text {ns }}$ & $0.70^{\text {ns }}$ & $0.47^{\text {ns }}$ & $2.28^{\text {ns }}$ & $0.73^{\text {ns }}$ \\
\hline & $\mathrm{F} 0.01$ & 8.65 & 98.50 & 8.65 & 8.65 & 98.50 & 8.65 & 8.65 & 98.50 & 8.65 & 8.65 & 98.50 & 8.65 \\
\hline
\end{tabular}

$R=$ plant age during submergence; $C=$ cultivar; ${ }^{* *}=$ highly significant; ${ }^{*}=$ significant; $n s=$ non-significant .

After experiencing a recovery phase of 4 days, R3 plants had an increase in leaf greenness values compared to the value after submergence which indicated an improvement in leaf chlorophyll content. Likewise, when compared to other treatments, the increase in leaf 
greenness in plant R3 was the highest during the 4 days of recovery (Fig 2). However, when compared with other treatments through the LSD test, R3 plants still had the lowest mean absolute value of 26.6 while the highest was in treatment $R 1$ with a value of 42.7 (Table 5). During 7, 10 and 14 days of recovery, only leaf greenness level was significantly affected by the difference on plant age, while other parameters remained the same. This indicated that all plants in all ages showed the same tendency or the same recovery pattern, while the difference on leaf greenness parameter was more likely affected by plant age as aforementioned.

Table 4 - LSD test of interaction factor between cultivar and plant age during submergence treatment $(R)$ on leaf area increment, stem dry weight, leaf dry weight and total dry weight increment after 4 days recovery

\begin{tabular}{|c|c|c|c|c|c|c|c|}
\hline Cultivar & $\mathrm{R} 1$ & & $\mathrm{R} 2$ & & R3 & & LSD 0.05 \\
\hline \multicolumn{8}{|c|}{ Leaf area increment $\left(\mathrm{cm}^{2}\right)$} \\
\hline IR 42 & 136.2 & $b B$ & 10.2 & aA & 7.6 & $\mathrm{aA}$ & \multirow[t]{2}{*}{5.34} \\
\hline Inpari 30 & $(11.3)$ & $a A$ & 62.0 & $\mathrm{cA}$ & 4.0 & $\mathrm{bA}$ & \\
\hline \multicolumn{8}{|c|}{ LSD $0.05=142.27$} \\
\hline \multicolumn{8}{|c|}{ Stem dry weight increment $(g)$} \\
\hline IR 42 & 1.22 & $\mathrm{bA}$ & $(0.18)$ & aA & 0.04 & $a b A$ & \multirow[t]{2}{*}{1.20} \\
\hline Inpari 30 & 0.14 & $\mathrm{aA}$ & 1.07 & $\mathrm{aA}$ & $(0.03)$ & $\mathrm{aA}$ & \\
\hline \multicolumn{8}{|c|}{ LSD $0.05=1.53$} \\
\hline Leaf dry & nent $(g)$ & & & & & & \multirow{3}{*}{0.55} \\
\hline IR 42 & 0.76 & $b A$ & $(0.20)$ & $a A$ & 0.01 & $\mathrm{aA}$ & \\
\hline Inpari 30 & 0.04 & $a A$ & 0.26 & $\mathrm{aA}$ & 0.01 & $\mathrm{aA}$ & \\
\hline \multicolumn{8}{|c|}{ LSD $0.05=0.77$} \\
\hline \multicolumn{8}{|c|}{ Total dry weight increment $(g)$} \\
\hline IR 42 & 3.83 & $\mathrm{aB}$ & $(0.20)$ & $\mathrm{aA}$ & 0.05 & $\mathrm{aA}$ & \multirow[t]{2}{*}{5.33} \\
\hline Inpari 30 & $(0.24)$ & $\mathrm{aA}$ & 2.56 & $\mathrm{aA}$ & $(0.02)$ & $\mathrm{aA}$ & \\
\hline
\end{tabular}

The numbers followed by the same lower case letter in the same row and the same capital letter in the same column indicates non-significant difference on LSD 0.05. Numbers in the brackets indicate negative values.

Based on LSD test results in Table 5, it was showed that R3 treatment remains the treatment with the lowest green leaf value at 10 days of recovery with 35.4 . This value had actually increased considerably compared to the value in the previous phases, but was still significantly the smallest when compared to the R1 and R2 treatments in the 10-day recovery phase. This can also be seen in Fig 2, where R3 treatment on the IR 42 variety has an average value that was almost the same as the R1 treatment of Inpari 30. This indicated an increase in leaf chlorophyll levels which may be due to the recovery of plant metabolism after experiencing a 10 day recovery period after being submerged.

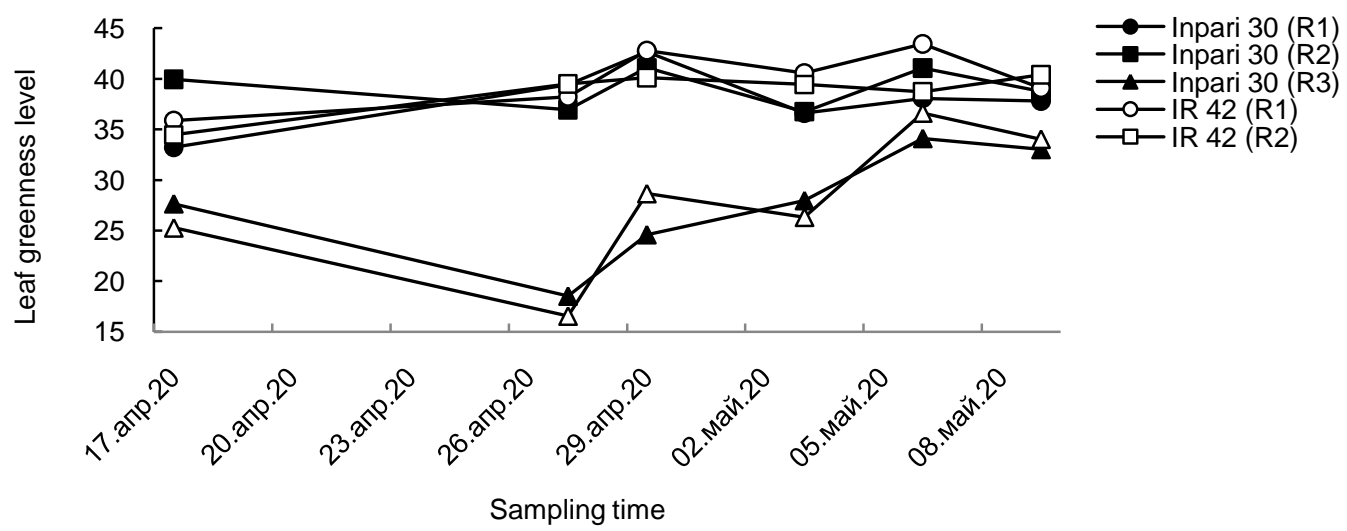

Figure 2 - Leaf greenness level of two rice cultivars during 10 days submergence and 14 days recovery phase 
Table 5 - LSD test of plant age during submergence treatment $(R)$ on leaf greenness level after $4,7,10$ and 14 days of recovery

\begin{tabular}{|c|c|c|}
\hline Treatment & Leaf greenness level & \\
\hline & 4 days recovery & \\
\hline R1 & 42,7 & b \\
\hline R2 & 40,6 & b \\
\hline R3 & 26,6 & a \\
\hline LSD 0.01 & 6.24 & \\
\hline & 7 days recovery & \\
\hline R1 & 38,6 & b \\
\hline $\mathrm{R} 2$ & 38,1 & b \\
\hline R3 & 27,1 & a \\
\hline LSD 0.01 & 5.70 & \\
\hline & 10 days recovery & \\
\hline R1 & 40,8 & b \\
\hline $\mathrm{R} 2$ & 39,9 & b \\
\hline R3 & 35,4 & a \\
\hline LSD 0.05 & 3.38 & \\
\hline & 14 days recovery & \\
\hline R1 & 38,4 & b \\
\hline $\mathrm{R} 2$ & 39,6 & b \\
\hline R3 & 33,5 & a \\
\hline LSD 0.05 & 4.55 & \\
\hline
\end{tabular}

The numbers followed by the same letter in the same column indicates non-significant difference on LSD 0.01 and 0.05. Numbers in the brackets indicate negative values.

Based on analysis of variance on Table 3, stem dry weight increment at 10 days recovery was significantly affected by the difference on plant age. Plants in treatment $R 2$ had the highest increment value with $1.23 \mathrm{~g}$ which was significantly different from treatment $\mathrm{R} 3$ with $0.06 \mathrm{~g}$ but not significantly different from treatment R1 of $0.82 \mathrm{~g}$ (Table 6). There was no longer a negative value in this phase indicating an increase in the accumulation of photosynthate in the plant stem. This of course pointed out that plant metabolism had started to return to normal.

Table 6 - LSD test of plant age during submergence treatment $(R)$ on stem dry weight increment after 10 days of recovery

\begin{tabular}{lll}
\hline Treatment & Stem dry weight increment at 10 days recovery & \\
\hline R1 & 0.82 & ab \\
R2 & 1.23 & $\mathrm{~b}$ \\
R3 & 0.06 & $\mathrm{a}$ \\
\hline LSD 0.05 & 0.89 & \\
\hline
\end{tabular}

The numbers followed by the same letter in the same column indicates non-significant difference on LSD 0.05 .

In general, the observed growth parameters did not give a significant response to the treatment, but based on the increase in the mean value, the trend of recovery pattern of rice plants in each cultivar and treatment could be evaluated. Fig 3 shows the increase in mean root length during submergence and recovery phases. Rice root length during submergence showed insignificant changes, except for treatment R1 of IR 42 variety. During the recovery period, the pattern of root length increase was relatively the same, except for treatment R2 of Inpari 30 . While root growth characteristics in this research was not noticeable, tolerant plant actually would tend to have longer roots during submergence as reported by Bui et al. (2019). 


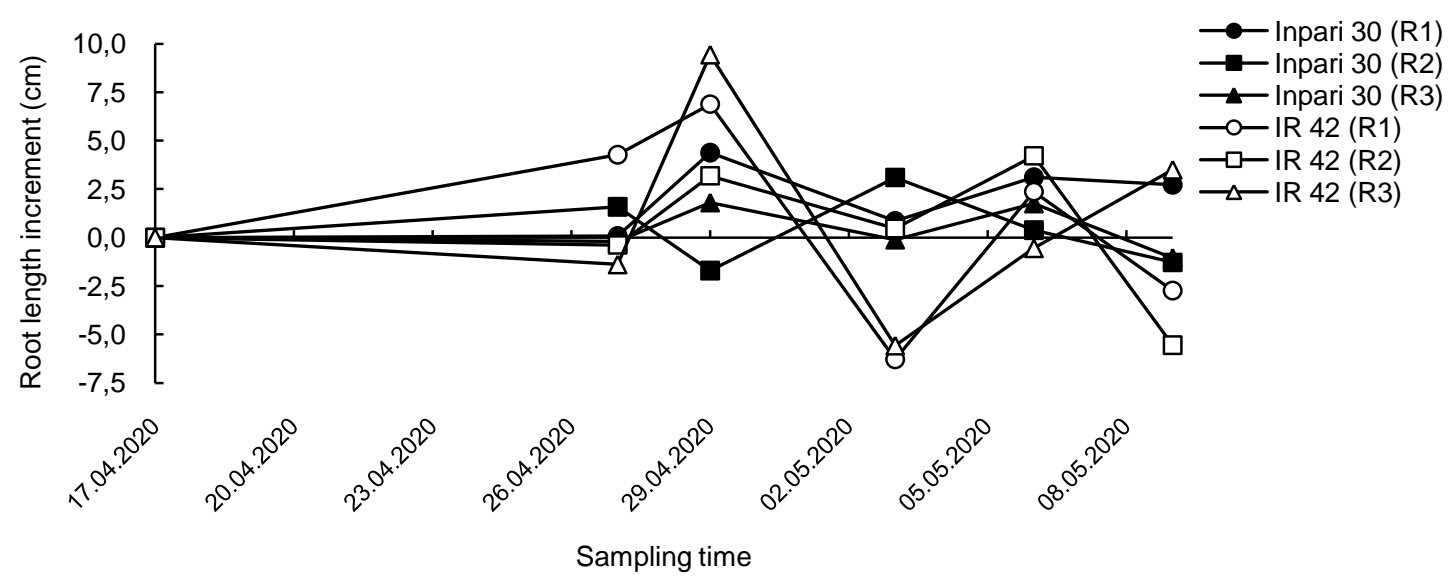

Figure 3 - Root length increment of two rice cultivars during 10 days submergence and 14 days recovery phase

The results also showed that during 10 days submergence, all plants in all treatments experienced a decrease in leaf area which then increased in the initial 4 days of recovery period. At 7 days of recovery, leaf area tends to decrease due to the occurrence of senescence on the leaves. Leaf area improvement began to appear at 10 days of recovery (Fig 4).

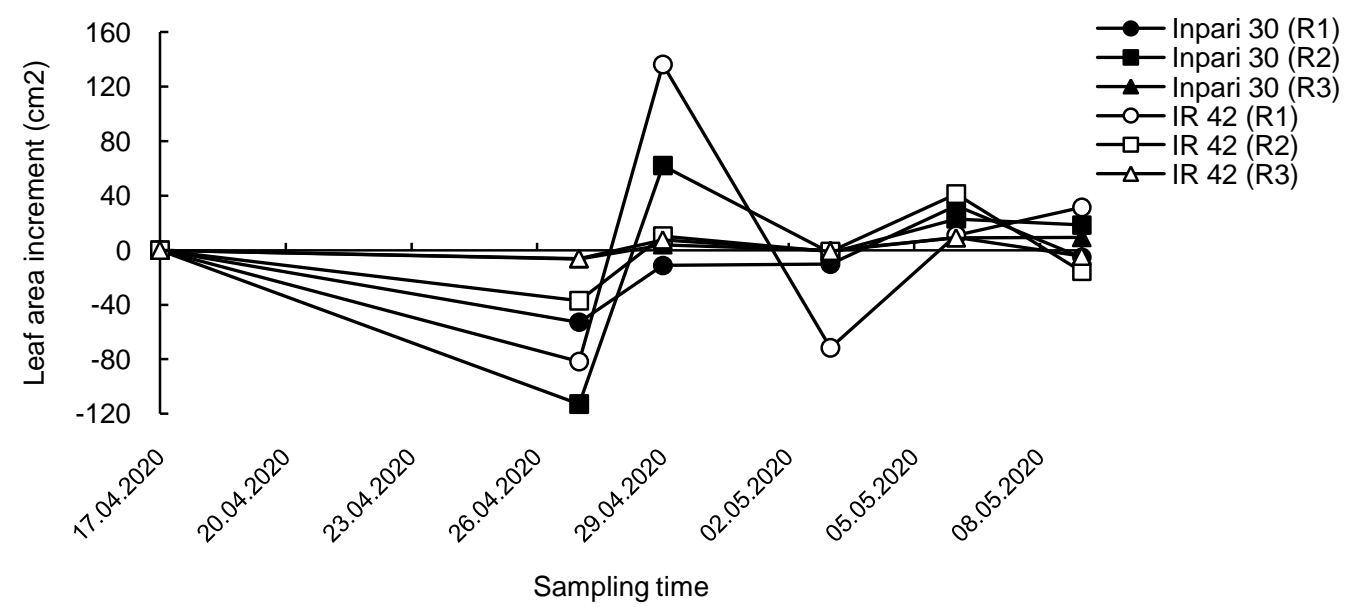

Figure 4 - Leaf area increment of two rice cultivars during 10 days submergence and 14 days recovery phase

\section{CONCLUSION}

Based on the results, it was concluded: 1) The recovery pattern of rice plants after submergence stress was generally not influenced by plant age since all plants in all ages showed similar response; 2) Improvement in plant growth characters after being submerged began to appear after 10 days of recovery.

\section{ACKNOWLEDGEMENTS}

We would like to express our gratitude to Rector of University of Sriwijaya through Research and Community Service Center under Sains, Teknologi and Seni (SAINTEK) research scheme had funded this research by the contract number 0163.109/UN9/SB3.LPPM.PT/2020, on July 23, 2020. 


\section{REFERENCES}

1. Anandan, A., Rajiv, G., Ramarao, A., \& Prakash, M. (2012). Internode elongation pattern and differential response of rice genotypes to varying levels of flood water. Functional Plant Biology. https://doi.org/10.1071/FP11184.

2. Bailey-Serres, J., Fukao, T., Ronald, P., Ismail, A., Heuer, S., \& Mackill, D. (2010). Submergence tolerant rice: SUB1's journey from landrace to modern cultivar. Rice. https://doi.org/10.1007/s12284-010-9048-5.

3. Bui, L. T., Ella, E. S., Dionisio-Sese, M. L., \& Ismail, A. M. (2019). Morpho-Physiological Changes in Roots of Rice Seedling upon Submergence. Rice Science. https://doi.org/10.1016/j.rsci.2019.04.003.

4. Buraschi, F. B., Mollard, F. P. O., Grimoldi, A. A., \& Striker, G. G. (2020). Eco-physiological traits related to recovery from complete submergence in the model legume lotus japonicas. Plants. https://doi.org/10.3390/plants9040538.

5. Elanchezhian, R., Kumar, S., Singh, S. S., Dwivedi, S. K., Shivani, S., \& Bhatt, B. P. (2013). Plant survival, growth and yield attributing traits of rice (Oryza sativa L.) genotypes under submergence stress in rainfed lowland ecosystem. Indian Journal of Plant Physiology. https://doi.org/10.1007/s40502-013-0050-y.

6. Gautam, P., Nayak, A. K., Lal, B., Bhattacharyya, P., Tripathi, R., Shahid, M., Mohanty, S., Raja, R., \& Panda, B. B. (2014). Submergence tolerance in relation to application time of nitrogen and phosphorus in rice (Oryza sativa L.). Environmental and Experimental Botany. https://doi.org/10.1016/j.envexpbot.2013.11.012.

7. Irmawati, Ehara, H., Kodama, I., Osawa, M., Suwignyo, R. A., Junaedi, A., \& Sakagami, J.-I. (2016). Growth Characteristics of Two Indonesian Rice Cultivars under Several Submergence Durations. Tropical Agriculture and Development, 60(1), 40-47.

8. Luo, F. L., Nagel, K. A., Scharr, H., Zeng, B., Schurr, U., \& Matsubara, S. (2011). Recovery dynamics of growth, photosynthesis and carbohydrate accumulation after de-submergence: A comparison between two wetland plants showing escape and quiescence strategies. Annals of Botany. https://doi.org/10.1093/aob/mcq212.

9. Manzanilla, D. O., Paris, T. R., Vergara, G. V., Ismail, A. M., Pandey, S., Labios, R. V., Tatlonghari, G. T., Acda, R. D., Chi, T. T. N., Duoangsila, K., Siliphouthone, I., Manikmas, M. O. A., \& Mackill, D. J. (2011). Submergence risks and farmers' preferences: Implications for breeding Sub1 rice in Southeast Asia. Agricultural Systems. https://doi.org/10.1016/j.agsy.2010.12.005.

10. Nishiuchi, S., Yamauchi, T., Takahashi, H., Kotula, L. (2012). Mechanisms for coping with submergence andwaterlogging in rice. In Rice. https://doi.org/10.1186/1939-8433-5-2.

11. Oladosu, Y., Rafii, M. Y., Arolu, F., Chukwu, S. C., Muhammad, I., Kareem, I., Salisu, M. A., \& Arolu, I. W. (2020). Submergence tolerance in rice: Review of mechanism, breeding and, future prospects. In Sustainability (Switzerland). https://doi.org/10.3390/su12041632.

12. Panda, D., \& Sarkar, R. K. (2014). Mechanism associated with nonstructural carbohydrate accumulation in submergence tolerant rice (Oryza sativa L.) cultivars. Journal of Plant Interactions. https://doi.org/10.1080/17429145.2012.763000.

13. Revatipadale et al., R. et al. . (2019). Estimation of Chlorophyll Content in Young and Adult Leaves of Some Selected Plants in Non-Polluted Areas. International Journal of Botany and Research. https://doi.org/10.24247/ijbrjun20194.

14. Singh, S., Mackill, D. J., \& Ismail, A. M. (2014). Physiological basis of tolerance to complete submergence in rice involves genetic factors in addition to the SUB1 gene. AoB PLANTS. https://doi.org/10.1093/aobpla/plu060.

15. Ye, X. Q., Meng, J. L., Zeng, B., Wu, M., Zhang, Y. Y., \& Zhang, X. P. (2016). Submergence causes similar carbohydrate starvation but faster post-stress recovery than darkness in Alternanthera philoxeroides plants. PLoS ONE. 